\title{
Discrimination of prostate cancer cells and non-malignant cells using secondary ion mass spectrometry
}

\author{
Matthew J. Baker, ${ }^{* a}$ Michael D. Brown, ${ }^{b}$ Ehsan Gazi, ${ }^{b}$ Noel W. Clarke, ${ }^{b c d}$ John C. Vickerman ${ }^{a}$ and \\ Nicholas P. Lockyer ${ }^{a}$
}

Received 21st August 2007, Accepted 21st November 2007

First published as an Advance Article on the web 30th November 2007

DOI: $10.1039 / \mathrm{b} 712853 \mathrm{c}$

This communication utilises Time-of-Flight Secondary Ion Mass Spectrometry (ToF-SIMS) combined with multivariate analysis to obtain spectra from the surfaces of three closely related cell lines allowing their discrimination based upon mass spectral ions.

Prostate Cancer $(\mathrm{CaP})$ is the most common male cancer and the second most common cause of cancer-related death of men in the UK. ${ }^{1}$ CaP preferentially metastasises to the bone marrow and the resulting bone metastases are directly responsible for considerable mortality and morbidity. At present, Prostate Specific Antigen (PSA) is used to identify patients at higher risk of CaP. This is followed by a biopsy for histopathological assessment using the Gleason grading system.

It has been shown that the PSA blood test can be misleading in the diagnosis of prostate cancer ${ }^{2}$ and a study by Latouff and Saad showed that Gleason grading varies between pathologists with identical grades assigned to only $29.2 \%$ of tumours. ${ }^{3}$ The varied prognostic outcome and need for a robust/intervention therapy makes $\mathrm{CaP}$ an ideal model to develop chemically-based prognostic indicators.

Time-of-Flight Secondary Ion Mass Spectrometry (ToF-SIMS) is a surface analysis technique whereby a surface is bombarded with a high energy $(\mathrm{keV})$ 'primary' ion beam. This results in the ejection, or 'sputtering' of 'secondary' molecular and fragment ions that reflect the detailed surface chemistry of the area under analysis. The secondary ions are analysed using a high sensitivity time-of-flight mass analyser. Ion flight times are converted into mass-to-charge $(\mathrm{m} / \mathrm{z})$ values using known calibration parameters.

Under atomic primary ion bombardment, the sputter yield of intact molecular ions or fragments emitted from the top monolayers is low and chemicals accumulate in the surface region. Further chemical information on the undamaged surface can only be obtained up to the so-called 'static limit' (corresponding to a primary ion dose of $1 \times 10^{12}$ ions $\mathrm{cm}^{-2}$ ), ensuring that a fresh area is analysed with each primary ion impact. The development of

\footnotetext{
${ }^{a}$ Manchester Interdisciplinary Biocentre, Centre for Instrumentation and Analytical Science, School of Chemical Engineering and Analytical Science, The University of Manchester, UK M1 7DN. E-mail: M.Baker2@postgrad.manchester.ac.uk

${ }^{b}$ ProMPT Genito Urinary Cancer Research Group, Paterson Institute for Cancer Research, The University of Manchester, Christie Hospital NHS Foundation Trust, Manchester, UK M20 4BX

${ }^{c}$ Department of Urology, Christie Hospital NHS Foundation Trust, Manchester, UK M20 4BX

${ }^{d}$ Department of Urology, Salford Royal NHS Foundation Trust, Salford, UK M6 $8 H D$
}

cluster and polyatomic primary ion beams including $\mathrm{Au}_{n}{ }^{+}, \mathrm{Bi}_{n}{ }^{+}$, $\mathrm{SF}_{5}{ }^{+}$and $\mathrm{C}_{60}{ }^{+}$has significantly enhanced the sensitivity of the ToF-SIMS technique in (bio)molecular analysis. ${ }^{4}$ Under polyatomic bombardment the static limit can in some circumstances be lifted as the sputter yield is sufficiently high to remove the majority of surface damage under certain conditions. ${ }^{11}$ SIMS spectra, like those derived from other desorption mass spectrometric methods contain a relatively high degree of fragmentation. The $\mathrm{C}_{60}{ }^{+}$ primary ion beam used in this study has been shown to increase the yield of molecular or parent ions from biomolecular samples. ${ }^{5}$ Although even under $\mathrm{C}_{60}{ }^{+}$bombardment the SIMS process does not typically result in significant yields of high mass biomolecules $(>$ a few $\mathrm{kDa})$, the key advantages of the technique are its surface sensitivity ( $c$. $1-2 \mathrm{~nm})$, high spatial resolution $(<\mu \mathrm{m})$ and the fact that the sample does not have to be chemically modified to make it amenable to analysis. Hence the technique is well suited to mapping relatively low molecular weight compounds in biological cells. In this work we explore the capability of ToF-SIMS to differentiate cells based on surface chemical analysis.

Two prostate cancer cell lines and a prostatic epithelial cell line were utilised: (1) PC-3, a human prostate cancer epithelial cell line derived from bone metastases; (2) LNCaP, a human prostate cancer epithelial cell line derived from lymph node metastases; and (3) PNT2-C2, an immortalised non-malignant normal adult prostatic epithelial cell line. Cells were cultured on silicon substrates in Hams F-12, 7\% Foetal Calf Serum (FCS) and $2 \mathrm{mM}$ L-glutamine to $80 \%$ confluence at $37{ }^{\circ} \mathrm{C}$ in a humidified atmosphere of $5 \% \mathrm{CO}_{2}$ in air. Following culture, cells were washed for $3 \mathrm{~s}$ in phosphate buffered saline (PBS) and for $60 \mathrm{~s}$ in deionised $\mathrm{H}_{2} \mathrm{O}$ prior to flash-freezing in liquid nitrogen-cooled methyl-2butane. The samples were prepared in a Heto Drywinner freezedryer at ca. $1 \times 10^{-3}$ mbar at a temperature of $-110{ }^{\circ} \mathrm{C}$ in the cold trap. ToF-SIMS analysis was carried out on a BioToF-SIMS instrument ${ }^{6}$ with a $40 \mathrm{keV} \mathrm{C}_{60}{ }^{+}$primary ion beam. Each analysis was performed over a $500 \times 500 \mu \mathrm{m}^{2}$ field-of-view, corresponding to a primary ion dose density $<1 \times 10^{10}$ ions $\mathrm{cm}^{-2}$. Charge compensation was employed using $25 \mathrm{eV}$ electrons between ion pulses. Positively charged secondary ions in the mass range of $1-$ $2000 \mathrm{Da}$ were recorded. Fifteen samples, from 15 different cultures of each cell line were analysed, with three different areas of each sample analysed. By way of example, Fig. 1 shows a positive ion mass spectrum taken from a freeze-dried sample of PC-3 cells. This resulted in a total of 135 mass spectra. The presence of a high level of sodium can influence the relative intensity of other species in the ToF-SIMS spectrum through the matrix effect. ${ }^{7}$ For this reason all spectra with sodium intensity greater than $10 \%$ of the total signal 


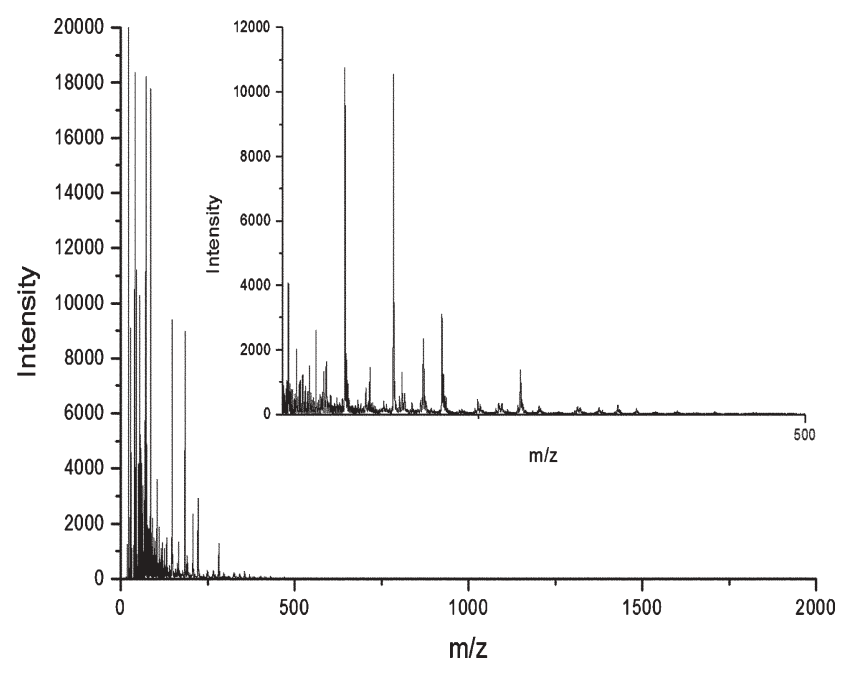

Fig. 1 Typical positive SIMS spectrum of PC-3 cell line over a $500 \times$ $500 \mu \mathrm{m}^{2}$ area.

were discarded. The resulting filtered spectra, 36 spectra for PC-3, 20 spectra for LNCaP and 32 spectra for PNT2-C2, were preprocessed by sum-normalisation. This normalises the total area of the spectrum to one and expresses the peak intensities as a ratio of that sum.

Principal Component-Discriminant Function Analysis (PCDFA) uses Principal Component Analysis (PCA) to reduce the dimensionality of the data prior to DFA. DFA then discriminates between groups on the basis of the resulting PCs and the a priori knowledge of group memberships that are fed into the DFA algorithm. ${ }^{8}$ In this case the model uses 44 principal components and two discriminant functions. The maximum number of discriminant functions available for use is the number of groups (e.g. number of cell lines) minus one. The optimum number of principal components was determined through an iterative process of chemometric model generation and validation. DFA is a supervised technique, the model is supplied with information about group membership, so any result produced by the model needs to be validated. The model was validated by retaining one-fifth of the total filtered pre-processed spectra, in this case 17 randomly selected spectra, and then supplying the spectra to the model as a blind test and observing where the model places the spectra. Fig. 2A shows the discriminant function plot showing separation based upon the training set, Fig. 2B shows the discriminant training function plot with the training set and blind test set, and Fig. 2C shows the loadings plots for Discriminant Function 1 and 2 which show the mass spectral peaks responsible for this discrimination.

Discriminant Function 1 is discriminating the PC-3 cell line from the PNT2-C2 and LNCaP cell lines, separating the cell line derived from bone metastases from cell lines derived from lymph node metastases and normal prostatic epithelial cells. Discriminant Function 2 is discriminating the PNT2-C2 cell line from the $\mathrm{PC}-3$ and $\mathrm{LNCaP}$, discriminating the normal prostatic cell line from the malignant cell lines. Table 1(A) shows the sensitivities and specificities for the different cell lines at the 95\% (pink ellipse) and 99\% (green ellipse) confidence limits based on our validation set (see Fig. 2B). Sensitivity is the probability of obtaining a positive result from people with the disease, which is the ability of the model to diagnose. Specificity is the probability of a negative test among patients without the disease, or the ability of the model to not misdiagnose. Table 1(B) shows the proposed mass spectral assignments for Discriminant Function 1 and Table 1(C) for Discriminant Function 2. The axes of the discriminant function plot have positive and negative directions (Fig. 2C). The peaks in the positive direction of the $y$-axis of the DF1 loadings plot correspond to the mass spectral ions which the model is using to discriminate the LNCaP and PNT2 cell line from the PC-3 cell line. The peaks in the negative direction correspond to the mass spectral ions used to discriminate the PC-3 cell line from the LNCaP and PNT2 cell lines. The peaks in the positive direction of the DF2 loading plot are used to discriminate the PC-3 and LNCaP cell lines from the PNT2 cell line and the peaks in the negative direction are used to discriminate the PNT2 cell line from the PC-3 and LNCaP cell lines.

At the $99 \%$ confidence limit only one spectrum was misclassified. A spectrum from the PNT2-C2 cell line was classified as a PC-3 spectrum. The specificity for the model as a whole is high and, therefore, it could be said, that the model has the ability to not misdiagnose. The sensitivity differs for the PC-3 and LNCaP cell line between the confidence limits, with the greatest difference seen in the PNT-C2 group. The high sensitivity for the model at the $99 \%$ confidence limit demonstrates the ability to diagnose.

A detailed interpretation of the mass spectral signatures associated with chemically complex materials such as biological cells is very challenging. Chemometric analysis simplifies this task by highlighting the significant mass spectral difference between closely related samples, providing a subset of peaks on which the analyst can focus. In this work, analysis was performed under static SIMS conditions, in which each primary ion impacts a previously undisturbed region of the sample. The resulting mass spectra reflect the outermost molecular layers of the sample, in this case presumably intact cell membranes. This is consistent with the appearance of many spectral features that can be assigned to lipid-related ions. In addition to membrane lipids a number of amino-acid-related ions are apparent. These signals may rise from transmembrane proteins. The proposed assignments point towards a difference in phospholipid content, with the cancerous cell lines discriminating upon a phosphocholine or sphingomyelin and the transformed normal cell line discriminating upon phosphoethanolamine. Elevated phosphocholine levels have previously been associated with cellular proliferation, an aspect of cancer. ${ }^{9}$

This study has shown ToF-SIMS to be capable of cell line discrimination based upon surface chemical differences. Further work of this type may assist the identification of potential diagnostic and prognostic indicators in prostate cancer and other diseases. The spatial resolution of the ToF-SIMS technique is such that it is capable of generating mass spectral data from single cells, as has been demonstrated on numerous occasions. ${ }^{12}$ Thus it can be envisaged that the discriminatory power of the technique demonstrated in this work could be extended to single cells in a mixed population or tissue biopsy. Under polyatomic ion bombardment a steady state 

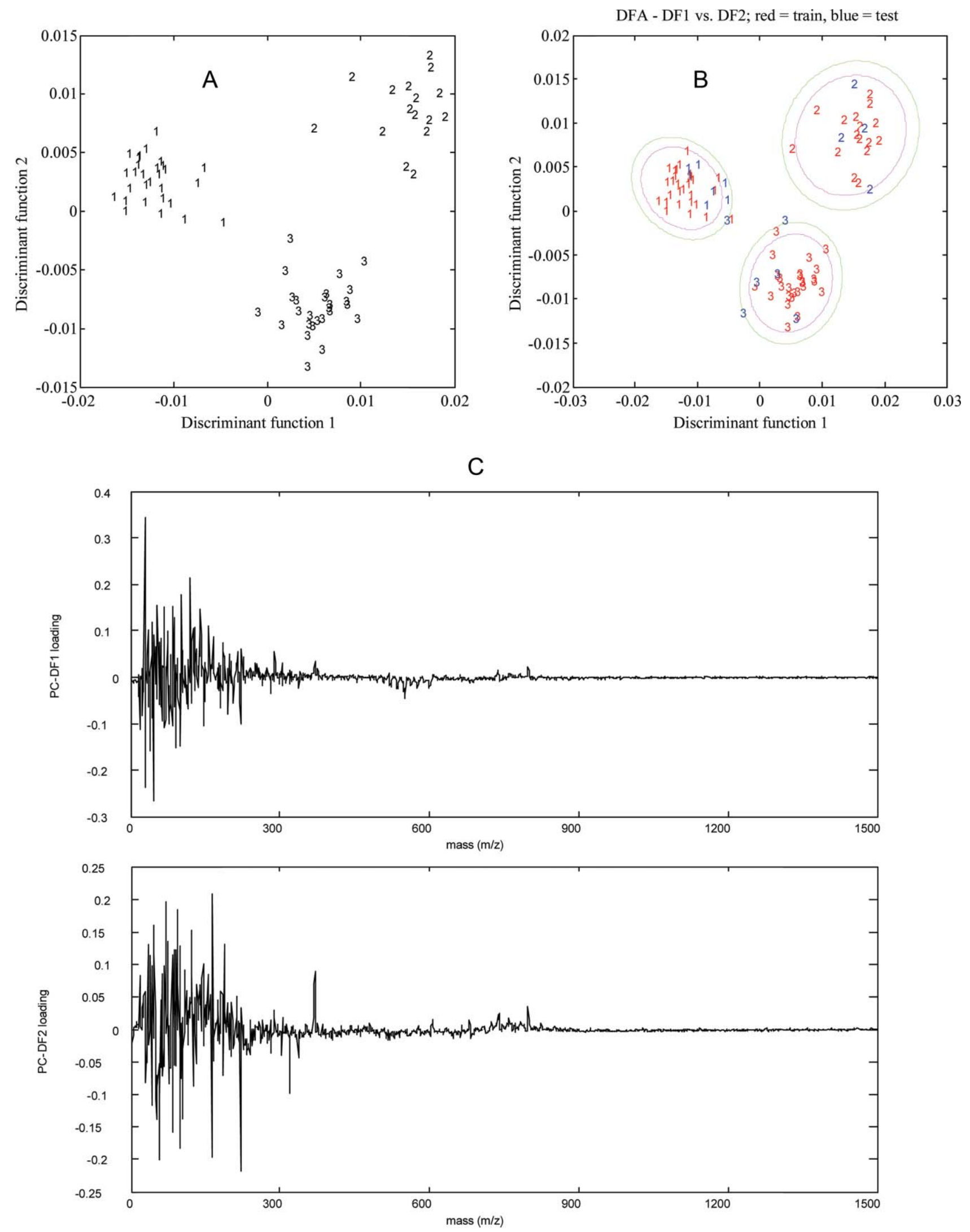

Fig. 2 (A) Discriminant function plot showing separation based upon the training set. $1=$ PC-3, $2=$ LNCaP, $3=$ PNT2. (B) Discriminant function projection plot with the training set in red and the blind set in blue, showing confidence limits of $95 \%$ (pink ellipse) and 99\% (green ellipse). $1=$ PC-3, $2=$ LNCaP, 3 = PNT2. (C) Loadings plots for Discriminant Function 1 and 2 which show the mass spectral peaks responsible for the discrimination. 
Table 1 (A) Sensitivities and specificities for the different cell lines at the 95\% (pink ellipse) and 99\% (green ellipse) confidence limits of Fig. 2; (B) shows the proposed mass spectral assignments for Discriminant Function 1 and (C) Discriminant Function 2

\begin{tabular}{llcr}
\hline A & & & \\
\hline Cell line & Confidence limit (\%) & Sensitivity (\%) & Specificity (\%) \\
\hline PC-3 & 95 & 71.4 & 100 \\
& 99 & 100 & 90 \\
LNCaP & 95 & 100 & 100 \\
& 99 & 100 & 100 \\
PNT2 & 95 & 50 & 100 \\
& 99 & 83.3 & 100
\end{tabular}

\begin{tabular}{|c|c|c|}
\hline \multicolumn{3}{|l|}{ B } \\
\hline Loading direction & $m / z$ & Proposed structure and parent compound \\
\hline$+\mathrm{ve}$ & 59 & {$\left[\mathrm{C}_{2} \mathrm{H}_{3} \mathrm{O}_{2}\right]^{+}-$valine } \\
\hline$+\mathrm{ve}$ & 166 & {$\left[\mathrm{C}_{4} \mathrm{H}_{13} \mathrm{NO}_{3} \mathrm{P}\right]^{+}-$phosphocholine or sphingomyelin } \\
\hline$+\mathrm{ve}$ & 213 & {$\left[\mathrm{C}_{6} \mathrm{H}_{14} \mathrm{PO}_{6}\right]^{+}-$phosphoglycerol } \\
\hline$+\mathrm{ve}$ & 224 & {$\left[\mathrm{C}_{8} \mathrm{H}_{19} \mathrm{PO}_{4} \mathrm{~N}\right]^{+}-$phosphocholine or sphingomyelin } \\
\hline$+\mathrm{ve}$ & 235 & {$\left[\mathrm{C}_{6} \mathrm{H}_{13} \mathrm{PO}_{6} \mathrm{Na}\right]^{+}-$phosphoglycerol } \\
\hline$-\mathrm{ve}$ & 30 & {$\left[\mathrm{CH}_{4} \mathrm{~N}\right]^{+}-$glycine } \\
\hline$-\mathrm{ve}$ & 100 & {$\left[\mathrm{C}_{4} \mathrm{H}_{10} \mathrm{~N}_{3}\right]^{+}-$arginine } \\
\hline$-\mathrm{ve}$ & 104 & {$\left[\mathrm{C}_{5} \mathrm{H}_{14} \mathrm{NO}\right]^{+}-$phosphocholine or sphingomyelin } \\
\hline$-\mathrm{ve}$ & 112 & {$\left[\mathrm{C}_{5} \mathrm{H}_{10} \mathrm{~N}_{3}\right]^{+}$- arginine } \\
\hline$-\mathrm{ve}$ & 130 & {$\left[\mathrm{C}_{9} \mathrm{H}_{8} \mathrm{~N}\right]^{+}-$tryptophan } \\
\hline$-\mathrm{ve}$ & 159 & {$\left[\mathrm{C}_{10} \mathrm{H}_{11} \mathrm{~N}_{2}\right]^{+}-$tryptophan } \\
\hline$-\mathrm{ve}$ & 175 & {$\left[\mathrm{C}_{6} \mathrm{H}_{15} \mathrm{~N}_{4} \mathrm{O}_{2}\right]^{+}-$arginine } \\
\hline$-\mathrm{ve}$ & 184 & {$\left[\mathrm{C}_{5} \mathrm{H}_{15} \mathrm{NO}_{4} \mathrm{P}\right]^{+}-$phosphocholine or sphingomyelin } \\
\hline$-\mathrm{ve}$ & 256 & {$\left[\mathrm{C}_{16} \mathrm{H}_{34} \mathrm{NO}^{+}\right.$- palmitoyl from sphingosine backbone } \\
\hline$-\mathrm{ve}$ & 281 & {$\left[\mathrm{C}_{18} \mathrm{H}_{33} \mathrm{O}_{2}\right]^{+}$- oleoyl single fatty acid side chain or free acid } \\
\hline$-\mathrm{ve}$ & 313 & {$\left[\mathrm{C}_{19} \mathrm{H}_{37} \mathrm{O}_{3}\right]^{+}$- palmitoyl with glycerol backbone from phospholipid } \\
\hline$-\mathrm{ve}$ & 339 & {$\left[\mathrm{C}_{21} \mathrm{H}_{39} \mathrm{O}_{3}\right]^{+}-$oleoyl with glycerol backbone from phospholipid } \\
\hline$-\mathrm{ve}$ & 341 & {$\left[\mathrm{C}_{21} \mathrm{H}_{41} \mathrm{O}_{3}\right]^{+}$- stearoyl with glycerol backbone from phospholipid } \\
\hline$-\mathrm{ve}$ & 551 & {$\left[\mathrm{C}_{35} \mathrm{H}_{67} \mathrm{O}_{4}\right]^{+}$- dipalmitoyl with glycerol backbone from phospholipid } \\
\hline$-\mathrm{ve}$ & 577 & {$\left[\mathrm{C}_{37} \mathrm{H}_{64} \mathrm{O}_{4}\right]^{+}-$palmitoyl and oleoyl with glycerol backbone from phospholipid } \\
\hline \multicolumn{3}{|l|}{$\mathbf{C}$} \\
\hline Loading direction & $m / z$ & Proposed structure and parent compound \\
\hline$+\mathrm{ve}$ & 122 & {$\left[\mathrm{C}_{3} \mathrm{H}_{8} \mathrm{NO}_{2} \mathrm{~S}\right]^{+}-$cysteine } \\
\hline$+\mathrm{ve}$ & 134 & {$\left[\mathrm{C}_{4} \mathrm{H}_{8} \mathrm{NO}_{4}\right]$ - alanine or aspartic acid } \\
\hline$+\mathrm{ve}$ & 136 & {$\left[\mathrm{C}_{8} \mathrm{H}_{10} \mathrm{NO}\right]^{+}-$tyrosine } \\
\hline$+\mathrm{ve}$ & 143 & {$\left[\mathrm{C}_{2} \mathrm{H}_{8} \mathrm{O}_{5} \mathrm{P}\right]^{+}$- phosphoserine } \\
\hline \multirow[t]{2}{*}{$+\mathrm{ve}$} & 165 & {$\left[\mathrm{C}_{9} \mathrm{H}_{11} \mathrm{NO}_{2}\right]^{+}-$tyrosine, or } \\
\hline & & {$\left[\mathrm{C}_{2} \mathrm{H}_{7} \mathrm{O}_{5} \mathrm{PNa}\right]-$ phosphoserine } \\
\hline$+\mathrm{ve}$ & 184 & {$\left[\mathrm{C}_{5} \mathrm{H}_{15} \mathrm{NO}_{4} \mathrm{P}\right]^{+}-$phosphocholine or sphingomyelin } \\
\hline$+\mathrm{ve}$ & 224 & {$\left[\mathrm{C}_{5} \mathrm{H}_{15} \mathrm{NO}_{4} \mathrm{P}\right]^{+}-$phosphocholine or sphingomyelin } \\
\hline$+\mathrm{ve}$ & 313 & {$\left[\mathrm{C}_{19} \mathrm{H}_{37} \mathrm{O}_{3}\right]^{+}$- palmitoyl with glycerol backbone from phospholipid } \\
\hline$+\mathrm{ve}$ & 339 & {$\left[\mathrm{C}_{21} \mathrm{H}_{39} \mathrm{O}_{3}\right]^{+}$- oleoyl with glycerol backbone from phospholipid } \\
\hline$-\mathrm{ve}$ & 30 & {$\left[\mathrm{CH}_{4} \mathrm{~N}\right]^{+}-$glycine } \\
\hline$-\mathrm{ve}$ & 68 & {$\left[\mathrm{C}_{4} \mathrm{H}_{6} \mathrm{~N}\right]^{+}$- proline } \\
\hline$-\mathrm{ve}$ & 70 & {$\left[\mathrm{C}_{4} \mathrm{H}_{8} \mathrm{~N}\right]^{+}$- proline } \\
\hline$-\mathrm{ve}$ & 142 & {$\left[\mathrm{C}_{2} \mathrm{H}_{9} \mathrm{NO}_{4} \mathrm{P}\right]^{+}-$phosphoethanolamine } \\
\hline$-\mathrm{ve}$ & 231 & {$\left[\mathrm{C}_{10} \mathrm{H}_{10} \mathrm{~N}_{2} \mathrm{O}_{4}\right]^{+}-$proline } \\
\hline$-\mathrm{ve}$ & 281 & {$\left[\mathrm{C}_{18} \mathrm{H}_{33} \mathrm{O}_{2}\right]^{+}-$oleoyl single fatty acid side chain or free acid } \\
\hline
\end{tabular}

condition may be reached in which the sample is stable to further ion fluence, facilitating molecular characterisation and depth profiling beyond the static limit. ${ }^{5}$ Recently this ToF-SIMS modality has been applied to biological cells. ${ }^{10}$ An extension of this chemometric study to the cellular sub-surface may provide additional insight into the chemical differences between related cell lines.

The authors would like to acknowledge the Royal Society of Chemistry, EPSRC Life Sciences Interface Programme, BBSRC and The Association for International Cancer Research for funding support

\section{Notes and references}

1 CancerStats, Mortality-UK, Cancer Research UK, http://info. cancerresearchuk.org/cancerstats/types/prostate/mortality/?a $=5541$ (accessed 23rd November 2007).

2 T. A. Stamey, M. Caldwell, J. E. McNeal, R. Nolley, M. Hermenz and J. Downs, J. Urol., 2004, 172, 1297-1301.

3 J. B. Lattouf and F. Saad, Br. J. Urol. Int., 2002, 90, 694-699.

4 J. Cheng and N. Winograd, Anal. Chem., 2005, 77(11), 3651-3659.

5 J. S. Fletcher, X. A. Conlan, E. A. Jones, G. Biddulph, N. P. Lockyer and J. C. Vickerman, Anal. Chem., 2006, 78(6), 1827-1831.

6 R. M. Braun, P. Blenkinsopp, S. J. Mullock, C. Corlett, K. F. Wiley, J. C. Vickerman and N. Winograd, Rapid Commun. Mass Spectrom., 1998, 12(18), 1246-1252. 
7 M. S. Wagner, B. J. Tyler and D. G. Castner, Anal. Chem., 2002, 74, 1824-1835.

8 R. M. Jarvis and R. Goodacre, Anal. Chem., 2004, 76(1), $40-47$.

9 J. Kurhanewicz, D. B. Vingeron and S. J. Nelson, Neoplasia, 2000, 2(1-2), 166-189.
10 J. S. Fletcher, N. P. Lockyer, S. Vaidyanathan and J. C. Vickerman, Anal. Chem., 2007, 79(6), 2199-2206.

11 J. S. Fletcher, N. P. Lockyer and J. C. Vickerman, Sur. Interface Anal., 2006, 38(11), 1393-1400.

12 L. A. McDonnell and R. M. A. Heeren, Mass Spectrom. Rev., 2007, 26(4), 606-643

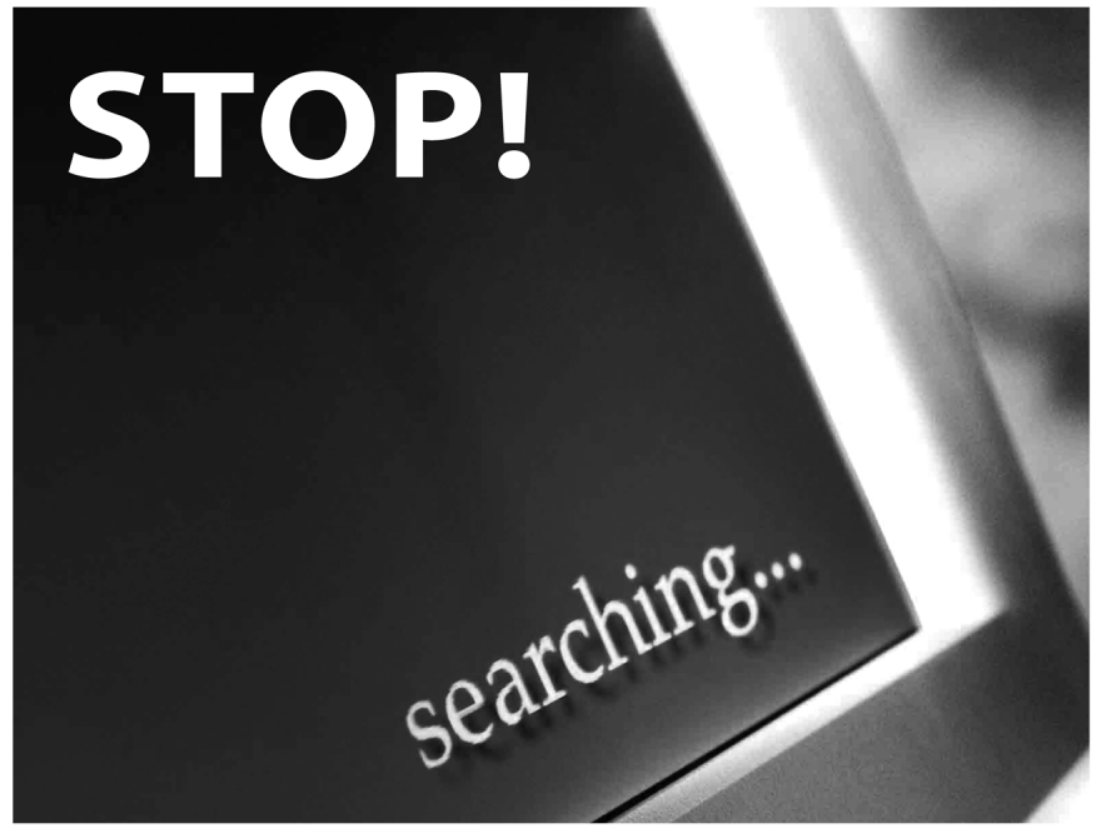

Save valuable time searching for that elusive piece of vital chemical information.

Let us do it for you at the Library and Information Centre of the RSC.

We are your chemical information support, providing:

- Chemical enquiry helpdesk

- Remote access chemical information resources

- Speedy response

- Expert chemical information specialist staff

Tap into the foremost source of chemical knowledge in Europe and send your enquiries to

\section{library@rsc.org}

